\title{
ANALISIS PENGARUH PROFITABILITAS (ROE), STRUKTUR MODAL (DER) DAN KEPUTUSAN INVESTASI (PER) TERHADAP NILAI PERUSAHAAN \\ (Studi Pada Perusahaan Sektor Properti dan Real Estate yang Terdaftar di Bursa Efek Indonesia (BEI) Periode 2011-2014)
}

\author{
Singgih Kurnianto \\ singgihkur@gmail.com \\ Universitas Ahmad Dahlan \\ Salamatun Asakdiyah \\ salamatun_2009@yahoo.com \\ Universitas Ahmad Dahlan
}

\begin{abstract}
ABSTRAK
This study aims to examine three independent variables Profitability (ROE), Capital Structure (DER) and Investment Decisions in predicts affect the dependent variable that is Company Value (Tobin's Q) in property and real estate companies listed on the Indonesia Stock Exchange (IDX) in the 2011-2014 period. This research method uses purposive sampling. Of the population of 40 companies that were sampled in the study were 26 companies. Tool the analysis used is linear regression analysis using the $t$ test (partially) and the $\mathrm{f}$ test (simultaneously) using the SPSS program for windows version 20.0. The results of the t-test show that Retutn On Equity (ROE), Debt Equity Ratio (DER) and Price On Earning Ratio (PER) are all three significantly positive effect on Tobin's Q. From the results of the $f$ test obtained the results that Retutn On Equity (ROE), Debt Equity Ratio (DER) and Price On Earning Ratio (PER) simultaneously influence Tobin's Q.
\end{abstract}

Keyword: Tobin's Q; Retutn On Equity; Debt Equity Ratio; Price On Earning Ratio.

\begin{abstract}
PENDAHULUAN
Perusahaan merupakan suatu organisasi yang terdiri dari sekelompok orang yang bekerja dengan tujuan untuk memperoleh keuntungan dan meningkatkan nilai perusahaan hingga mencapai maksimum. Nilai perusahaan merupakan harga yang layak dibayar oleh investor apabila perusahaan tersebut akan dilikuidasi (Fuad dkk, 2006:22). Untuk perusahaan yang menjual sahamnya kepada masyarakat (go public), harga saham yang diperjualbelikan di Bursa Efek juga menjadi salah satu indikator yang mempengaruhi nilai perusahaan (Fuad dkk, 2006:23).
\end{abstract}

Nilai perusahaan atau corporate value merupakan point penting bagi pemegang saham, karena kemakmuran pemegang saham direfleksikan dengan nilai perusahaan yang tinggi. Untuk mencapai nilai perusahaan yang maksimal, maka perusahaan harus dikelola dengan baik (Sartono:2010). Untuk mencapai nilai perusahaan maksimum ada beberapa faktor yang harus di perhatikan oleh manajer yaitu, Profitabilitas, Struktur Modal dan Keputusan investasi. Ketiga faktor tersebut diprediksikan dapat mempengaruhi tinggi rendahnya nilai perusahaan. dan investasi (Rahmawati,Topowijono \& Sulasmiyati:2013) Rasio profitabilitas terdiri atas profit margin, basic earning power, return on assets, dan return on equity. Weston dan Copeland (2008) mendefinisikan probabilitas sejauh mana perusahaan menghasilkan laba dari penjualan dan investasi perusahaan. 
Apabila profitabitas perusahaan baik maka para stakeholders yang terdiri dari kreditur, supplier, dan juga investor akan melihat sejauh mana perusahaan dapat menghasilkan laba dari penjualan dan investasi perusahaan. Dengan baiknya kinerja perusahaan akan meningkatkan pula nilai perusahaan (Suharli, 2006 (Rahmawati dkk, 2015)). Dalam penelitian yang dilakukan oleh Santika dan Kusuma (2002) dalam Rahmwati dkk (2015) pengaruh profitabilitas sebagai indikator kinerja perusahaan berpengaruh positif terhadap perusahaan. Karena dengan meningkatnya kinerja perusahaan akan meningkatkan ROA dan ROE yang merupakan contoh proksi dari rasio profitabilitas Struktur modal perusahaan, dapat dilihat dari besaran hutang dengan cara mengukur kemampuan perusahaan untuk memenuhi seluruh kewajiban finansialnya yang terdiri dari utang jangka menengah dan utang jangka panjang terhadap ekuitas. Struktur modal dalam penelitian ini diwakili oleh Debt Equity Ratio (DER). DER merupakan rasio yang membandingkan total hutang jangka panjang dan menengah terhadap total ekuitas perusahaan. Rasio ini mengukur persentase kepemilikan hutang perusahaan. DER mencerminkan kemampuan perusahaan untuk mengelola hutang jangka menengah dan jangka panjang. Semakin besar rasio ini menunjukkan bahwa semakin besar kewajiban perusahaan dibanding ekuitas yang dimiliki perusahaan (Adri:2014).

Keputusan investasi berhubungan langsung dengan perusahaan, dalam artian bahwa keputusan investasi erat kaitannya dengan kegiatan investasi yang dilakukan oleh perusahaan. Sudana (2011) menyatakan bahwa "keputusan investasi berkaitan dengan proses pemilihan satu atau lebih alternatif investasi yang dinilai menguntungkan dari sejumlah alternatif investasi yang tersedia bagi perusahaan". Keputusan investasi dapat mempengaruhi nilai perusahaan karena dengan komposisi investasi yang baik akan dapat menarik investor untuk berinvestasi pada perusahaan tersebut.

Sektor properti dan real estate merupakan salah satu diantara beberapa sektor saham yang ada di BEI. Perusahaan yang bergerak dalam sektor properti dan real estate saat ini berkembang dengan pesat. Kemajuan dan perkembangan bisnis ini menjadi daya tarik bagi para investor untuk berinvestasi pada perusahaan sektor properti dan real estate. Investor mengerti bahwa sektor properti dan real estate mempunyai prospek yang baik kedepannya (Azizah dkk :2013)

\section{Rumusan Masalah}

1. Bagaimana pengaruh profitabilitas terhadap nilai perusahaan?

2. Bagaimana pengaruh struktur modal terhadap nilai perusahaan?

3. Bagaimana pengaruh keputusan investasi terhadap nilai perusahaan?

4. Bagaimana pengaruh profitabilitas, struktur modal dan keputusan investasi terhadap nilai perusahaan?

\section{REVIEW LITERATUR DAN HIPOTESIS}

\section{Landasan Teori \\ Nilai perusahaan}

Menurut Brigham dan Houston (2006) dalam Rahmi (2014) Nilai perusahaan didefinisikan sebagai nilai pasar karena nilai perusahaan dapat memberikan kemakmuran pemegang saham secara maksimum apabila harga saham perusahaan meningkat. Berbagai kebijakan yang diambil oleh manajemen dalam upaya untuk meningkatkan nilai perusahaan melalui peningkatan kemakmuran pemilik dan para pemegang saham yang tercermin pada harga saham.

\section{Profitabilitas}

Salah satu indikator penting bagi investor dalam menilai prospek perusahaan di masa depan adalah dengan melihat 
sejauh mana pertumbuhan profitabilitas perusahaan (Tandelilin, 2007). Profitabilitas menurut Saidi (2004) dalam Martalina (2011) dalam Rahmi (2014) adalah kemampuan perusahaan dalam memperoleh laba. Menurut Sartono (2001) dalam rahmi 2014, protabilitas adalah kemampuan perusahaan memperoleh laba dalam hubungan dengan penjualan, total aktiva maupun modal sendiri. Para investor tetap tertarik terhadap profitabilitas perusahaan karena profitabilitas merupakan satu-satunya indikator yang paling baik mengenai kesehatan keuangan perusahaan. Bagi perusahaan pada umumnya, masalah profitabilitas merupakan hal yang penting di samping masalahlaba, karena laba yang besar belum merupakan ukuran bahwa perusahaan telah bekerja secara efisien. Efisien baru dapat diketahui dengan membandingkan laba yang diperoleh dengan modal atau kekayaan yang digunkana untuk menghasilkan laba tersebut, atau dengan kata lain ialah menghitung profitabilitas

\section{Struktur Modal}

Menurut Martono dan Agus (2005) dalam Rahmi (2014) Struktur modal (capital structure) adalah perbandingan atau imbangan pendanaan jangka panjang perusahaan yang ditunjukkan oleh perbandingan hutang jangka panjang terhadap modal sendiri. Pemenuhan kebutuhan dana perusahaan bersumber dari modal sendiri yang berasal dari modal saham, laba ditahan, dan cadangan. Jika dalam pendanaan perusahaan yang berasal dari modal sendiri mengalami kekurangan (deficit) maka perlu dipertimbangkan pendanaan perusahaan yang berasal dari luar, yaitu hutang (debt financing). Namun dalam pemenuhan kebutuhan dana, perusahaan harus mencari alternatifalternatif pendanaan yang esfisien. Pendanaan yang efisien akan terjadi bila perusahaan mempunyai struktur modal yang optimal. Menurut Martono dan Agus (2005) dalam Rahmi (2014) Struktur modal yang optimal dapat diartikan sebagai struktur modal yang dapat meminimalkan biaya penggunaan modal keseluruhan atau biaya modal rata-rata.

\section{Investasi}

Keputusan investasi merupakan faktor penting dalam fungsi keuangan perusahaan. Menurut Fama (1978) dalam Afzal (2012) bahwa nilai perusahaan semata-mata ditentukan oleh keputusan investasi. Pendapat tersebut dapat diartikan bahwa keputusan investasi itu penting, karena untuk mencapai tujuan perusahaan yaitu memaksimumkan kemakmuran pemegang saham hanya akan dihasilkan melalui kegiatan investasi perusahaan. Keputusan investasi meliputi investasi pada aktiva jangka pendek (aktiva lancar) dan aktiva jangka panjang (aktiva tetap). Aktiva jangka pendek biasanya didefinisikan sebagai aktiva dengan jangka waktu kurang dari satu tahun atau kurang dari satu siklus bisnis, dalam hal ini dana yang diinvestasikan pada aktiva jangka pendek diharapkan akan diterima kembali dalam waktu dekat atau kurang dari satu tahun dan diterima sekaligus. Tujuan perusahaan berinvestasi pada aktiva jangka pendek adalah untuk digunakan sebagai modal kerja atau operasional perusahaan. Contoh aktiva jangka pendek adalah persediaan, piutang, dan kas. Sedangkan aktiva jangka panjang didefinisikan sebagai aktiva dengan jangka waktu lebih dari satu tahun, dalam hal ini dana yang ditanamkan pada aktiva jangka panjang akan diterima kembali dalam waktu lebih dari satu tahun dan kembalinya secara bertahap. Tujuan perusahaan berinvestasi pada aktiva jangka panjang adalah untuk meningkatkan nilai perusahaan (Hidayat,2010 (Afzal, 2012))

\section{Penelitian Terdahulu}

1. Dalam penelitian yang dilakukan oleh Amalia , Topojiwo dan Sulasmiyati (2013) yang berjudul "PENGARUH UKURAN PERUSAHAAN,PROFITABILITAS,ST UKTUR MODAL DAN 
KEPUTUSAN INVESTASI TERHADAP NILAI PERUSAHAAN (Studi pada Perusahaan Sektor Properti, Real Estate dan Building Construction yang Terdaftar di Bursa Efek Indonesia (BEI) Periode 2010-2013). Penelitian ini menunjukkan bahwa dari empat variabel tiga di antara nya berpengaruh terhadap nilai perusahaan,Variabel tersebut adalah Profitabilitas (arah hubungan positif), Struktur Modal (arah hubungan negatif) dan Keputusan Investasi (arah hubungan Positif). Penelitian ini juga menunjukkan bahwa ke empat variabel tersebut berpengaruh signifikan secara simultan terhadap nilai perusahaan.

2. Dalam penelitian yang dilakukan oleh Dewi dan Wirajaya (2013) yang berjudul "PENGARUH STRUKTUR MODAL, PROFITABILITAS DAN UKURAN PERUSAHAAN PADA NILAI PERUSAHAAN". Di dalam penelitiannya menunjukkan bahwa struktur modal berpengaruh negatif dan signifikan pada nilai perusahaan,dan profitabilitas berpengaruh positif dan signifikan pada nilai perusahaan.

3. Dalam penelitian yang dilakukan Septia (2015) yang berjudul "PENGARUH PROFITABILITAS, KEPUTUSAN INVESTASI, KEPUTUSAN PENDANAAN, DAN KEBIJAKAN DIVIDEN TERHADAP NILAI PERUSAHAAN PADA PERUSAHAAN MANUFAKTUR YANG TERDAFTAR DI BURSA EFEK INDONESIA". Di dalam penelitian ini menunjukkan bahwa Profitabilitas yang diproksikan dengan ROA (Return On Asset) berpengaruh positif dan signifikan terhadap nilai perusahaan pada perusahaan manufaktur di Bursa Efek Indonesia periode 2011-2013 dan Keputusan investasi yang diproksikan dengan PER (Price to Earnings Ratio) berpengaruh positif dan signifikan terhadap nilai perusahaan pada perusahaan manufaktur di Bursa Efek Indonesia periode 2011-2013.
4. Dalam penelitian yang dilakukan oleh Romadoni (2015) yang berjudul "PENGARUH STRUKTUR MODAL, PROFITABILITAS, UKURAN PERUSAHAAN DAN KEBIJAKAN DIVIDEN TERHADAP NILAI PERUSAHAAN (Studi Empiris Pada Perusahaan Manufaktur yang Terdaftar di Bursa Efek Indonesia Periode 2010-2012). Di dalam penelitian ini menunjukkan bahwa Struktur modal berpengaruh negatif dan secara statistik signifikan terhadap nilai perusahaan dan Profitabilitas berpengaruh positif dan secara statistik signifikan terhadap nilai perusahaan.

\section{Hipotesis}

H1: Profitabilitas (ROE) berpengaruh positif signifikan terhadap nilai perusahaan.

H2: Struktur Modal (DER) berpengaruh negatif signifikan terhadap nilai perusahaan.

H3: Keputusan Investasi (PER) berpengaruh positif signifikan terhadap nilai perusahaan

H4: Profitabilitas (ROE), Struktur Modal (DER) dan :Keputusan Investasi (PER) secara simultan berpengaruh signifikan terhadap Nilai Perusahaan.

\footnotetext{
METODE PENELITIAN

Populasi dan Sampel

Populasi adalah seluruh kumpulan elemen yang menunjukkan ciriciri tertentu dapat digunakan untuk membuat kesimpulan (Sanusi, 2011). Populasi yang diambil dalam peneltian ini terbatas meliputi perusahaan properti dan real estate yang terdaftar di Bursa Efek Indonesia (BEI) dan mempublikasikan laporan keuangan nya ke publik. Perusahaan yang menjadi populasi dalam penelitian ini adalah perusahaan yang listing di bawah tahun 2011 yang terdiri dari 40 perusahan properti dan real
} 
estate. Pembatasan populasi hanya meliputi perusahaan properti dan real estate yang mempublikasikan laporan keuangannya secara konsisten dari tahun 2011-2014.

Sampel adalah bagian dari elemen elemen populasi yang terpilih (Sanusi, 2011). Sampel dalam peneltian ini diambil dengan metode purposive sampling, yaitu cara pengambilan sampel yang didasarkan pada pertimbangan-pertimbangan.

\section{Definisi Operasional}

1. Variabel Independen

Profitabilitas/ Return On Equity (ROE) digunakan untuk mengukur kemampuan perusahaan dalam menghasilkan laba bersih yang dikaitkan dengan pembayaran dividen. Menurut Syamsuddin (2011) ROE diperoleh dengan rumus sebagai berikut :

$$
\text { ROE }=\frac{\text { Laba setelah pajak }}{\text { Total Equitas }} \times 100 \%
$$

Struktur Modal/ Debt to Equit Ratio (DER) digunakan untuk mengukur kemampuan perusahaan dalam memenuhi kewajiban dalam membayar hutangnya dengan jaminan modal sendiri. Selain itu rasio ini juga bias digunakan untuk mengukur perimbangan antara kewajiban yang dimiliki perusahaan dengan modal sendiri. Semakin tinggi rasio DER berarti modal sendiri yang digunakan semakin sedikit disbandinghutangnya. Perhitungan DER dilakukan dengan mengunakan rumus:

$$
\begin{aligned}
& \text { DER }=\frac{\text { Total Debt }}{\text { Total Equity }} \times 100 \% \\
& \text { Keputusan Investasi/ Price to } \\
& \text { Earning Ratio (PER) digunakan } \\
& \text { sebagai proksi atas ekspektasi investor } \\
& \text { dan penilaian pasar terhadap kinerja } \\
& \text { perusahaan (Saravanan,2014). PER } \\
& \text { mengindikasikan besarnya rupiah } \\
& \text { yang harus di bayarkan investor } \\
& \text { untuk memperoleh satu rupiah earning } \\
& \text { perusahaan (Tandelilin, 2010). Price } \\
& \text { to Earning Ratio (PER) dapat }
\end{aligned}
$$

dihitung dengan rumus sebagai berikut:

PER $=\frac{\text { Harga per lembar saham }}{\text { Laba bersih per saham }}$

2. Variabel Dependen

Variabel dependen adalah variabel yang dijelaskan atau dipengaruhi oleh variabel independen (Indriantoro dan Supomo, 2002). Variabel dependen dalam penelitian ini adalah nilai perusahaan properti dan real estate yang terdaftar di Bursa Efek Indonesia selama tahun 2011-2014. Secara formal penghitungan nilai perusahaan dengan menggunakan Tobin's Q, formulasi rasio Q Tobin menurut penelitianSudiyanti dan Puspitasari (2010) dinyatakan sebagai berikut:

\section{Teknik Analisis Data}

1. Analisis Regresi Berganda

Penelitian ini dilakukan dengan menggunakan metode regresi linier berganda. Secara umum, analisis regeresi adalah studi mengenai ketergantungan variabel dependen (terikat) dengan satu atau lebih variabel independen (bebas), dengan tujuan untuk mengestimasi dan atau memprediksi rata-rata populasi atau nilai rata-rata variabel dependen berdasarkan nilai variabel independen yang diketahui.

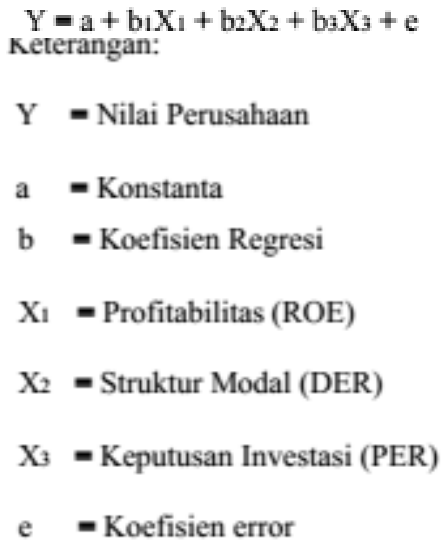




\section{Uji Asumsi Klasik}

Penggunaan uji asumsi klasik bertujuan untuk mengetahui dan menguji kelayakan atas model regresi yang digunakan pada penelitian ini. Sebelum mengolah data maka ditentukan alat statistik yang digunakan, dalam penelitian ini digunakan data SPSS.

\section{Uji Normalitas}

Menurut Sujarweni (2007) uji normalitas bertujuan untuk mengetahui distribusi dalam variabel yang akan digunakan dalam penelitian. Data yang baik dan layak digunakan dalam penelitian adalah data yang berdistribusi normal. Normalitas data dapat dilihat dengan menggunakan uji normal KolmogotovSmirnov. Data dikatan berdistribusi normal apabila signifikannya lebih besar dari $5 \%$ atau 0,05 .

\section{Uji Multikolineritas}

Menurut Sujarweni (2007:95) uji multikolinearitas diperlukan untuk mengetahui ada tidaknya variabel independen dalam suatu model. Kemiripan antar variabel independen akan mengakibatkan korelasi sangat kuat. Selain itu uji ini juga untuk menghindari kebiasan dalam proses pengambilan keputusan mengenai pengaruh pada uji parsial masingmasing variabel independen terhadap variabel dependen. Jika VIF yang dihasilkan antara 1-10 maka tidak terjadi multikolinearitas.

\section{Uji Autokorelasi}

Menurut Sujarweni (2007:95) uji autokorelasi dalam suatu model bertujuan untuk mengetahui ada tidaknya korelasi antara variabel pengganggu pada periode tertentu dengan variabel sebelumnya. Teknik pengujian autokorelasi adalah Durbin WatsonTest. Dengan pengambilan keputusan dapat dilakukan dengan membandingkan nilai D-W (d) dengan $\mathrm{D}-\mathrm{W}$ (dL dan dU). Dengan kriteria jika du<d hitung<4-du maka tidak terjadi korelasi.

\section{Uji Heteroskadastisitas}

Menurut Ghozali

heteroskadastisitas menguji terjadinya perbedaan variance residual suatu periode pengamatan ke periode pengamatan lain.

\section{Uji Hipotesis}

1. Uji Parsial (Uji T)

Uji parsial digunakan untuk mengetahui pengaruh masingmasing variabel independen terhadap variabel dependen. Pengujian ini dilakukan berdasarkan perbandingan nilai signifikansi masingmasing koefisiensi regresi. Dikatakan signifikan apabila nilai signifikansinya lebih kecil dari $5 \%$ atau 0,05 .

\section{Uji Simultan (Uji F)}

Uji pengaruh simultan digunakan untuk mengetahui apakah variabel independen secara bersama-sama atau simultan mempengaruhi variabel dependen. Pengujian ini dilakukan dengan menggunakan uji distribusi $\mathrm{F}$, yaitu dengan membandingkan nilai signifikansinya. Dikatakan signifikan apabila nilai signifikansinya lebih kecil dari $5 \%$ atau 0,05 .

\section{Uji Koefisien Determinasi}

Koefisien determinasi digunakan untuk mengukur seberapa jauh kemampuan model dalam menerangkan variasi variabel dependen. Nilai koefisien determinasi adalah antara nol dan satu. Nilai $\mathrm{R}_{2}$ yang kecil berarti kemampuan variabel independen dalam menjelaskan variabel dependen sangat terbatas. Nilai yang mendejati satu berarti variabel independen memberikan hampir semua informasi yang dibutuhkan untuk memprediksi variasi variabel dependen. 


\section{HASIL PENELITIAN DAN PEMBAHASAN}

\section{Statistik Deskriptif}

Tabel 4.1

\begin{tabular}{|c|c|c|c|c|}
\multicolumn{5}{c|}{ Hasil statistik deskriptif } \\
\hline Variabel & $\mathrm{N}$ & Mean & Maksimum & Minimum \\
\hline Roe & 104 &, 1340 &, 52 &, 0046 \\
\hline Der & 104 &, 9193 & 2,85 &, 15 \\
\hline Per & 104 & 21,8623 & 371,05 & 1,04 \\
\hline Tobin's Q & 104 &, 9525 & 8,08 &, 10 \\
\hline
\end{tabular}

Tabel 4.2

Tabel 4.2
\begin{tabular}{|c|c|c|c|c|}
\multicolumn{1}{c|}{ Hasil statistik deskriptif logaritma natural } \\
\hline Variabel & $\mathrm{N}$ & Mean & Maksimum & Minimum \\
\hline Roe & 104 & $-2,2727$ &,- 65 & $-5,38$ \\
\hline Der & 104 &,- 2503 & 1,05 & $-1,90$ \\
\hline Per & 104 & 2,5394 & 5,92 &, 04 \\
\hline Tobin's Q & 104 &,- 2951 & 2,09 & $-2,30$ \\
\hline
\end{tabular}

Sumber: Data sekunder, diolah (2015)

\section{Hasil Penelitian}

1. Hasil Uji Asumsi Klasik

Uji Normalitas

Uji Normalitas

Normal P.P Plot of Regression Standardized Residual

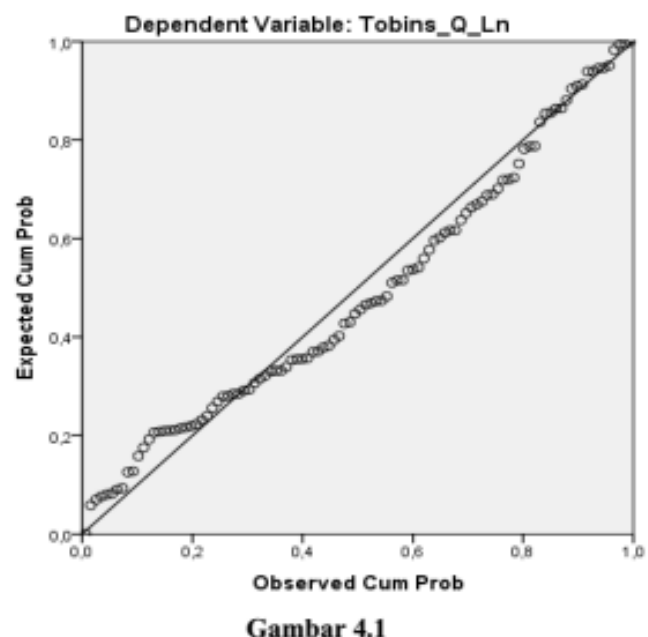

Gambar 4.1

Dari gambar 4.1 diatas dapat dilihat bahwa data menyebar disekitar diagram dan mengikuti model regresi. Sehingga dapatdisimpulkan bahwa data yang diolah merupakan data yang berdistribusi normal sehingga uji normalitas terpenuhi.

Uji Multikolineiritas

$$
\text { Tabel } 4.3
$$

Hasil Uji Multikolinieritas (Uji statistis VIF)

\begin{tabular}{|c|r|r|c|}
\multicolumn{5}{c|}{ (Uji statistis VIF) } \\
\hline $\begin{array}{c}\text { Variabel } \\
\text { independen }\end{array}$ & Tolerance & VIF & Kesimpulan \\
\hline ROE &, 476 & 2,099 & Tidak terjadi multikolinearitas \\
\hline DER &, 762 & 1,312 & Tidak terjadi multikolinearitas \\
\hline PER &, 586 & 1,707 & Tidak terjadi multikolinearitas \\
\hline
\end{tabular}

Hasil uji multikolinieritas menunjukkan bahwa nilai Tolerance ketiga variabel lebih dari 0.05 dan nilai VIF kurang dari 5. Jika nilai Tolerance $>0,05$ dan nilai VIF $<5$, maka dapat di simpulkan bahwa tidak terjadi multikolinieritas antar variabel independen dalam model regresi.

Uji Autokorelasi

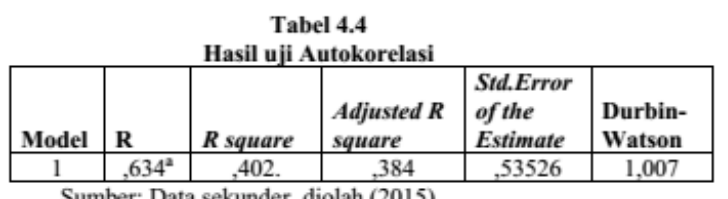

Uji Heterskedastisitas

uji Heteroskadastisitas

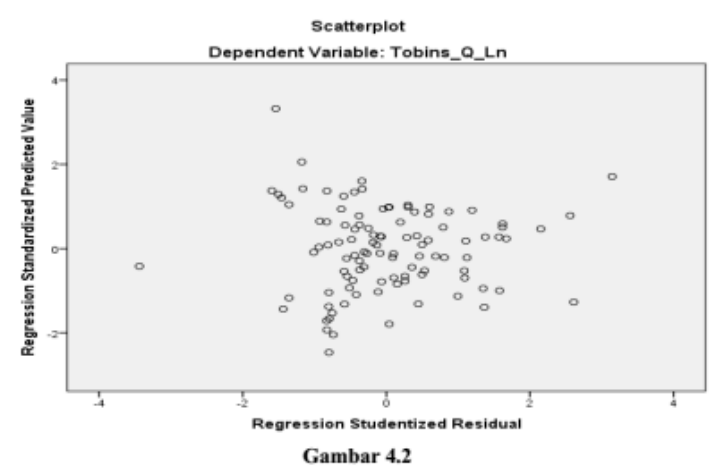

Hasil dari uji heteroskadastisitas dapat di lihat pada gambar 4.2 dengan menggunakan cara kolom plots, dengan hasil dapat dilihat pada gmabar pola grafiknya tidak jelas atau titik-titiknya menyebar tidak beraturan, maka hadil dari penelitian ini tidak terjadi heteroskadastisitas.

2. Hasil Uji Regresi Linier Berganda Tabel 4.5

Hasil uji analisis regresi linier berganda

\begin{tabular}{|c|c|c|c|}
\hline \multirow{2}{*}{ Model } & \multicolumn{2}{|c|}{ Unstandarddized coefficients } & \multirow{2}{*}{ Signifikansi } \\
\cline { 2 - 3 } & $\mathrm{B}$ & Std. Error & \\
\hline (Constant) & $-0,697$ & 0,178 & 0,000 \\
\hline ROE $\left(\mathrm{X}_{1}\right)$ & 0,194 & 0,090 & 0,033 \\
\hline DER $\left(\mathrm{X}_{2}\right)$ & 0,555 & 0,098 & 0,000 \\
\hline PER $\left(\mathrm{X}_{3}\right)$ & 0,387 & 0,080 & 0,000 \\
\hline \multicolumn{2}{|c|}{ Sumber: Data sekunder diolah $(2015)$} &
\end{tabular}

Sumber: Data sekunder, diolah (2015)

Tobin's Q $=-0,697+0,194 \mathrm{X}_{1}+0,555 \mathrm{X}_{2}+0,387 \mathrm{X}_{3}+\mathrm{e}$

1. Nilai konstanta sebesar $-0,697$ berarti jika variabel ROE, DER dan PER adalah nol maka nilai Tobin's 
Q pada perusahaan properti dan real estate akan sama dengan nilai konstanta yaitu sebesar -0.697

2. Koefisien regresi $\mathrm{ROE}\left(\mathrm{X}_{1}\right)$ sebesar 0.194 , berarti setiap kenaikan satu nilai nilai dari ROE maka akan memberikan kenaikan Tobin's Q pada perusahaan properti dan real estate sebesar 0,194 poin. Sebaliknya setiap penurunan satu nilai dari ROE maka akan memberikan penurunan pada Tobin's Q perusahaan properti dan real estate sebesar 0,194 poin.

3. Koefisien regresi DER $\left(\mathrm{X}_{2}\right)$ sebesar 0,555 berarti setiap kenaikan satu nilai nilai dari DER maka akan memberikan kenaikan Tobin's Q pada perusahaan properti dan rea estate sebesar 0,555 poin. Sebalikny setiap penuruna satu nilai dari DER maka akan memberikan penurunan pada Tobin's Q perusahaan properti dan real estate sebesar 0,555 poin.

4. Koefisien regresi $\operatorname{PER}\left(\mathrm{X}_{3}\right)$ sebesar 0.387 , berarti setiap kenaikan satu nilai nilai dari PER maka akan memberikan kenaikan Tobin's Q pada perusahaan properti dan real estate sebesar 0,387 poin. Sebaliknya setiap penuruna satu nilai dari PER maka akan memberikan penurunan pada Tobin's Q perusahaan properti dan real estate sebesar 0,387 poin.

\section{Hasil Uji Parsial (Uji T)}

Tabel 4.6

\section{Hasil Uji t}

\begin{tabular}{|c|c|c|c|}
\hline Variabel & t & Signifikansi & Kesimpulan \\
\hline ROE & 2,167 & 0,033 & $\mathrm{H}_{1}$ Diterima \\
\hline DER & 5,637 & 0,000 & $\mathrm{H}_{2}$ Ditolak \\
\hline PER & 4,811 & 0,000 & $\mathrm{H}_{3}$ Diterima \\
\hline \multicolumn{4}{|c}{ Sumber : Data sekunder, diolah (2015) }
\end{tabular}

Hasil uji t dapat dilihat pada tabel 4.6, diketahui nilai signifikansi Return On Equity (ROE) sebesar 0,033 lebih kecil dari signifikansi level 0,05 (0,033
$<0,05)$ oleh karena itu maka hipotesis $\left(\mathrm{H}_{1}\right)$ diterima. Sehingga dapat disimpulkan bahwa secara parsial Return On Equity berpengaruh positif terhadap nilai perusahaan properti dan realestate.

Hasil uji t dapat dilihat pada tabel 4.6, diketahui nilai signifikansi Debt Equity Ratio (DER) sebesar 0,033 lebih kecil dari signifikansi level 0,05 $(0,000<0,05)$ oleh karena itu maka hipotesis $\left(\mathrm{H}_{2}\right)$ ditolak. Sehingga dapat disimpulkan bahwa secara parsial Debt Equity Ratio berpengaruh positif terhadap nilai perusahaan properti dan real estate. Hasil uji t dapat dilihat pada tabel 4.6, diketahui nilai signifikansi Price to Earning Ratio (PER) sebesar 0,033 lebih kecil dari signifikansi level $0,05(0,000<0,05)$ oleh karena itu maka hipotesis $\left(\mathrm{H}_{3}\right)$ diterima. Sehingga dapat disimpulkan bahwa secara parsial Price to Earning Ratio berpengaruh positif terhadap nilai perusahaan properti dan real estate.

4. Hasil Uji Simultan (Uji F)

\begin{tabular}{|c|c|}
\multicolumn{2}{c}{ Tabel 4.7 } \\
Hasil Uji F \\
\hline F & Sig \\
\hline 22,428 & $0,000^{\mathrm{b}}$ \\
\hline Sumber: Data sekunder, diolah (2015)
\end{tabular}

Hasil uji F dari tabel diperoleh nilai signifikan 0,000 yang lebih kecil dari 0,05 , sehingga dapat disimpulkan variabel independen (ROE,DER dan PER) secara simultan berpengaruh signifikan terhadap nilai perusahaan properti dan real estate.

\section{Hasil Uji Koefisien Determinasi}

Koefisien determinan pada tabel summary diketahui bahwa nilai Adjusted $R$ Square sebesar 0,402 yang berarti bahwa variabel independen ROE, DER dan PER mampu menjelaskan perubahan variabel dependen yaitu Tobin's Q sebesar $40,2 \%$ sedangkan sisanya $59,8 \%$ di jelaskan di luar variabel yang digunakan dalam peneltian. 


\section{Pembahasan}

Dalam sub bab ini akan di bahas lebih jelas lagi satu persatu bagaimana perngaruh independen yang terdiri dari Return On Equity (ROE), Struktur Modal (DER) dan Keputusan Investasi (PER) terhadap variabel dependen yaitu Nilai Perusahaan (Tobin's Q). Rasio profitabilitas adalah rasio yang digunakan untuk mengukur seberapa efektif perusahaan dapat menghasilkan laba bagi perusahaan.

Hasil penelitian profitabilitas yang di proksikan dengan ROE, dapat di lihat uji diperoleh nilai signifikansi sebesar 0,000 hasil ini lebih kecil dari signifikansi level 0,05 dan nilai $t$ nya adalah sebesar 2,167. Maka dinyatakan bahwa Return On Equity berpengaruh signifikan positif terhadap nilai perusahaan (Tobin's Q). Dapat disimpulkan bahwa besar kecilnya profitabilitas akan mempengaruhi nilai perusahaan. Hasil ini sesuai dengan penelitian yang dilakukan oleh Rahmawati, Topowijono dan Sulasmiyati (2015) yang menemukan bahwa profitabilitas berpengaruh positif terhadap nilai perusahaan.

Struktur modal (capital structure) adalah perbandingan atau imbangan pendanaan jangka panjang perusahaan yang ditunjukkan oleh perbandingan hutang jangka panjang terhadap modal sendiri. Hasil penelitian struktur modal yang di proksikan dengan DER, dapat di lihat uji diperoleh nilai signifikansi sebesar 0,033 hasil ini lebih kecil dari signifikansi level 0,05 dan nilai $t$ nya adalah sebesar 5,637. Maka dinyatakan bahwa Debt Equity Ratio berpengaruh signifikan positif terhadap nilai perusahaan (Tobin's Q). Hal ini tidak sesuai dengan penelitian yang dilakukan oleh Rahmawati, Topowijono dan Sulasmiyati (2015) yang menemukan bahwa DER berpengaruh signifikan negatif terhadap nilai perusahaan. Namun, hal ini sesuai dengan penelitian yang dilakukan oleh Rizqia et al., (2013) yang menemukan bahwa DER berpengaruh signifikan positif terhadap nilai perusahaan. Perbedaan ini mungkin tren dari data perusahaan yang mengalami kenaikan yang terlalu tinggi dan penurunan yang terlalu rendah. Hal ini terbukti dengan dari tren data variabel DER dan Variabel Tobin's Q yang tidak stabil yang ada pada tabel lampiran 1 .

Keputusan investasi merupakan faktor penting dalam fungsi keuangan perusahaan. Fama (1978) dalam afzal (2012) menyatakan bahwa nilai perusahaan semata-mata ditentukan oleh keputusan investasi. Pendapat tersebut dapat diartikan bahwa keputusan investasi itu penting, karena untuk mencapai tujuan perusahaan yaitu memaksimumkan kemakmuran pemegang saham hanya akan dihasilkan melalui kegiatan investasi perusahaan. Hasil penelitian keputusan investasi yang di proksikan dengan PER, dapat di lihat uji diperoleh nilai signifikansi sebesar 0,000 hasil ini lebih kecil dari signifikansi level 0,05 dan nilai $\mathrm{t}$ nya adalah sebesar 4,811. Maka dinyatakan bahwa Price to Earning Ratio berpengaruh signifikan positif terhadap nilai perusahaan (Tobin's Q). Hal ini menunjukkan bahwa besar kecil nya investasi yang diberikan pada perusahaan berpengaruh terhadap nilai perusahaan. Hal ini sesuai dengan penelitian yang dilakukan oleh Rahmawati, Topowijono dan Sulasmiyati (2015) yang menemukan bahwa keputusan investasi berpengaruh positif terhadap nilai penelitian

\section{KESIMPULAN DAN SARAN}

\section{Kesimpulan}

Berdasarkan hasil analisis yang telah dilakukan peneliti, maka kesimpulan yang dapat diambil adalah sebagai berikut:

1. Profitabilitas berpengaruh signifikan positif terhadap nilai perusahaan properti dan real estate yang terdaftar di Bursa Efek Indonesia (BEI) periode 2011-2014.

2. Struktur Modal berpengaruh signifikan positif terhadap nilai perusahaan properti dan real estate yang terdaftar 
di Bursa Efek Indonesia (BEI) periode 2011-2014.

3. Keputusan Investasi berpengaruh signifikan positif terhadap nilai perusahaan properti dan real estate yang terdaftar di Bursa Efek Indonesia (BEI) periode 2011-2014.

4. Profitabilitas, Struktur Modal dan Keputusan Investasi berpengaruh signifikan secara simultan terhadap nilai perusahaan properti dan real estate yang terdaftar di Bursa Efek Indonesia (BEI) periode 2011-2014

\section{Saran}

Berdasarkan hasil penelitian, pembahasan dan kesimpulan, peneliti menyarankan beberapa hal, antara lain sebagaiberikut:

1. Peneliti selanjutnya diharapkan untuk mempertimbangkan pengambilan sempel yang lebih luas, baik dari segi periode pengamatan, kriteria data maupun jenis perusahaan yang diamati. Dengan demikian diharapkan memperoleh hasil koefisien yang dapat mencerminkan reaksi pasar sesungguhnya.

2. Peneliti selanjutnya diharapkan mempertimbangkan untuk menambah variabel independen yang akan diteliti, karena dengan tiga variabel saja dalam penelitian ini hanya mampu menjelaskan perubahaan variabel dependen sebesar 40,2\%, sedangkan sisanya 59,8 dijelaskan oleh variabel lain selain yang ada di dalam penelitian ini. Variabel lain yang dapat ditambahkan seperti Return On Asset, Net Profit Margin dan lainlain.

\section{DAFTAR PUSTAKA}

Adri, Fazdlilah. 2014. Pengaruh Kepemilikan Manajerial. Struktur Modal, Kinerja Keuangan Terhadap Nilai Perusahaan (Property dan Real Estate). JOM FEKON. Vol. 1 no. 2 Oktober 2014.pp 2.
Afzal dan Rohmah. 2012. Pengaruh Keputusan Investasi,Keputusan Pendanaan dan Kebijakan Deviden Terhadap Nilai Perusahaan. Jurnal Akuntansi Universitas Diponegoro. Semarang.

Afzal, Arie. 2012. Pengaruh Keputusan Investasi ,Keputusan Pendanaan dan Kebijakan Deviden Terhadap Nilai Perusahaan. Skripsi. Universitas Diponegoro. Semarang

Amalia Dewi Rahmawati, Topowijono dan Sri Sulasmiyati. 2015. Pengaruh Ukuran Perusahaan, Profitabilitas, Struktur Modal, dan Keputusan Investasi Terhadap Nilai Perusahaan (Studi pada Perusahaan Sektor Properti, Real Estate, dan Building Construction yang Terdaftar di Bursa Efek Indonesia (BEI) Periode 20102013).

Jurnal Aministrasi Bisnis. Vol. 23 No. 2 Juni 2015 Availaible from : www.administrasibisnis.studentjourn al.ub.ac.id

Amirul, Hadi dan Haryono, H. 2006. Metodologi Penelitian Pendidikan. Bandung: Pustaka Setia.

Dewi, Ayu Sri Mahatma dan Ary Wirajaya. 2013. Pengaruh Struktur Modal, Profitabilitas Dan Ukuran Perusahaan Pada Nilai Perusahaan. E-Jurnal Akuntansi Universitas Udayana 4.2, 358-372.

Dimas Prasetyo Zahroh Z.A dan Devi Farah Azizah. 2013. Pengaruh Keputusan Investasi dan Pendanaan terhadap Nilai Perusahaan (Studi pada Perusahaan Sektor Properti dan Real Estate yang Terdaftar di BEI Periode Tahun 2009-2011. Jurnal Fakultas Administrasi. Universitas Brawijaya. 
Fuad M., H Christin., Nurlela, Sugiarto., YEF Paulus., 2006, Pengantar Bisnis,. Jakarta: Gramedia Pustaka Utama

Ghozali, Imam. 2011. Aplikasi Analisis Multivariate dan Program IBM SPSS 19(edisi Kelima).Semarang: Universitas Diponegoro.

Indriantoro, Nur dan Bambang Supomo. 2002. Metode Penelitian. Edisi 1. Yogyakarta: BPFE

Kurniawati, Indah. 2010. Pengolahan Data Elektronik. Yogyakarta. Badan Penerbit Fakultas Ekonomi. Universitas Ahmad Dahlan.

Rahmi, Fahla Amalina. 2014. PENGARUH PROFITABILITAS DAN STRUKTUR MODAL TERHADAP NILAI PERUSAHAAN (Studi Empiris pada Perusahaan Sektor Agriculture yang Terdaftar di Bursa Efek Indonesia Periode 2010-2013).

Skripsi. Universitas Widyautama. Bandung.

Sanusi,Anwar. 2011. Metode Penelitian Bisnis. Jakarta: Salemba Empat.

Sartono, Agus. 2010. Manajemen Keuangan Teori dan Aplikasi. Edisi 4. Yogyakarta: BPFE.

Sudana, I Made. 2011. Manajemen Keuangan Perusahaan. Erlangga, Jakarta.

Sugiyono. 2003. Metode Penelitian Bisnis. Edisi 1, Bandung: Alfabeta.

Sujarweni, V. Wiratna. (2007). Belajar Mudah SPSS untuk Penelitian Skripsi, Tesis, Desertasi, dan Umum. Yogyakarta: Ardana Media.
Sutrisno. 2012. Manajemen Keuangan Teori, Konsep dan Aplikasi. Yogyakarta : EKONISIA.

Syamsuddin, Lukman., 2011. Manajemen Keuangan Perusahaan. Edisi Kesebelas. Jakarta : Grafindo

Tandelilin, Eduardus. 2007. Analisis Investasi dan Manajemen. Portofolio (Edisi Pertama, Cetakan Kedua). Yogyakarta: BPFE

Tandelilin, Eduardus. 2010. Potofolio dan Investasi Teori dan Aplikasi. Kanius. Yogyakarta

Weston, J.F dan Copelan. 2008. DasarDasar Manajemen Keuangan Jilid II. Jakarta: Erlangga 